\title{
IMPLEMENTING WRITING PROCESS APPROACH WITH PICTURES TO IMPROVE THE ABILITY OF THE EIGHTH GRADES IN WRITING RECOUNTS
}

\author{
Muhammad Lukman Syafii \\ Mubammadiyah University of Ponorogo \\ s.muhammadlukman@yahoo.com
}

\begin{abstract}
Writing skill has an important role in the English teaching program in Islamic Junior High School. However, the ability of the eighth-graders of this school in writing is still dissatisfactory. The students feel still difficulties how to start writing and they don't have an idea to write. This research is intended to progress the writing skill of the eighth graders by implementing a writing process approach with pictures. This strategy is chosen since it can lead the students to generate their ideas into a useful composition. The findings in the preliminary study show that the students need to learn how to start their writing and they do not have ideas to write. Only 8 of 31 students achieve the average score of writing skill equal to or above 70 . To get the purpose, the researcher conducted action research following four steps: planning, implementing, observing, and reflecting. The subject of the study were 31 students of the eighth grade. The findings show that implementing a writing process approach with pictures has progressed the writing skill of students. In cycle one, the students' average score was 15 of 31 failed and 16 of 31 students passed or got the score equal or greater than 70 . In cycle two, the average score for the final product was 6 of 31 students failed and 25 of 31 students passed or got the score equal or greater than 70 . Also, the findings of students revealed that the students' participation was active and motivated using pictures in the teaching and learning activities. Based on the results, it can be summarized that implementing a writing process approach with pictures is very beneficial not only in progressing the students' writing skill but also in motivating the students in the learning activities.
\end{abstract}

Keywords: using pictures, writing skill, recount text

\section{A. INTRODUCTION}

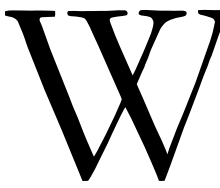

riting is the psichogocal work of finding ideas, thinking about how to express them and organizing them into statements and paragraphs that will be clear to a reader (Nunan, 2003). If writing is an important language skill to be studied, it is then also meant to be taught. Accordingly, English language learners' success in acquiring the capability to write in a foreign language depends on several extents on how teachers are able to teach writing skill to their students (Cahyono, 2009). Widiati and Cahyono (2006) emphasize that there are six purposes of teaching writing: writing for reinforcement, training, imitation, communication, fluency, and learning. The goal of teaching writing in MTs level is for learning.

There are five steps how to conduct the writing process (1) Assessing the writing situation: reflecting on the subject, one's attitude toward the subject, purpose, audience, sources of available explanations, and the writing tasks (2) Cruising and scheduling: finding, refining, finding support for, and organizing ideas (3) Drafting: expressing and developing 


\section{Volume 5, Number 2, December 2019}

ideas and supporting details in rough form (4) Revising: rethinking and rewriting drafts to improve the content, focus, and structure (5) Editing and proofreading: checking for effective word choice and sentence structure and for correct grammar, spelling, punctuation, and mechanics (Gardner, 2005).

Based on the writer's teaching experiences and observations on teaching writing in classroom activities, English teachers focus their teaching mostly on grammatical exercise and the product of writing. This means that some English teachers occasionally practice the teaching of writing, starting by only explaining the topic, the students will write about what the students listen from the teacher's explanation. No model text is provided. The students then are asked to write a short composition in certain time allotment. The teacher waits for the students' writing products without giving additional guidance. Finally, the students submit their work to the teacher. This teaching process cannot improve students' writing skill, so that classroom action research is needed. Besides teachers, they also become the researcher.

Classroom action research for English learning aims at discovering learning-teaching strategies that match learners' style and strategies in learning English (Latief, 2010). The researcher will use classroom action research because the students' competence of Eighth graders before giving this research is low to understand about how to write the recount text using simple past tense and their writing scores are less than 70 from minimum passing grade. So, the researcher wants to improve students' competence to make them better than before.

In addition, the previous English teacher never teaches English subject to students through pictures, therefore, this is the first classroom research using pictures. Why the researcher uses this class for doing research because they had experiences in the first grade and they did not focus on the National Examination. The role of pictures are as media in teaching and learning process in the classroom and should consist of a file of pictures, which can be used to give interesting atmosphere, meaning practice in the sound structure, writing and tense of the foreign language. By using this strategy the students are able to generate their ideas to start their writing.

In the teaching of English, one of the visual aids such as a picture is useful to be used because a picture can stimulate the students' competence in learning language, it can increase and focus the students' attention in learning the meaning of the word. It is able to make the class more tangible and active. Flickers won't make the students weary even if it is used for a long time. Harmer (2007) states that pictures can provide stimulation for writing-habit activities. Students are able to describe fickers or write descriptions of a wanted man or woman so that their colleagues have to identify that person from a group photograph. 
Buehl (2001) defines photograph as an image that can evoke a sense of mood and convey meaningful information that communicates far beyond written description. Photographs commonly capture the important moments of our lives, not only when we were happy but also when we were sad or upset. Furthermore, Fachrurrazy (2010) argues, pictures or photos are effective to teach any text types, such as descriptive, procedure, recount, and even argumentative texts.

In the preliminary research, the researcher observed the teaching writing recount texts, interviewed English teacher and analyzed the students writing recount texts. The result of the observation showed that the students need to learn how to start and they don't have an idea to write. The students' average score of writing skill is 60.62 . Only 8 of 32 students got scores equal to or above 70 .

Based on the problem stated above, the researcher decide to use pictures as a learning aids and strategy to overcome the students' problems in improving their writing recount texts because pictures can evoke students' interest and motivation, a sense of the context of the language, and a specific reference point or stimulus in teaching and learning activities in the classroom.

In this research, the students have to learn how to use the simple past tense in writing recount text because they need to learn the process of writing. It means that the process of writing is needed to build up to be their ability. If the process of writing is incorrect or wrongly ordered, it will be difficult to determine when the event occurs.

The school has 13 classes and each class has 4 classes except class 9, it has 5 classes. It has 6 English teachers. One of them is the researcher and English lesson is taught $4 \times 40$ minutes every week related to school Based Curriculum (Depdiknas, 2006).

The previous study about this research has been held by Fahrurrozi (2010) who used pictures to improve students' competence in making sentences for the eighth graders. Using this strategy, the writer can know the strategy and material that can improve the students' competence in making a sentence of this study is through visualization of pictures made students more understand and comprehend faster than talking and explaining the strategy.

\section{B. LITERATURE OF REVIEW}

It consists of reviews of relevant theories and studies concerning classroom action research, the teaching of writing at Islamic Junior High School, The Nature of Writing, The Process of Writing, Types of Paragraphs, Writing assessment, Pictures, and Previous researches. 


\section{The Teaching of Writing at Islamic Junior High School}

In general teaching of English in Islamic Junior High School or Junior High School, students, teachers, and parents who responded to the questionnaires cited that English instruction should not be just focused on the acquisition and superiority of the reading skill. This evidence is in line with reality in the teaching of English language skills such as listening, speaking, and writing is not provided or taught in the same proportions.

The writing skill has not been put something important in the teaching and learning activities in Junior High School. This condition is made because of some reasons. First, teaching writing is more minor proportion than reading skill in the classroom. Second, writing is not used in the National Examination. Consequently, the teachers and students think that reading skill is more important than writing skill. Third, some English teachers do not want to teach writing skill because it is difficult, needs much time to give scores and time allotment is limited for teaching the English language.

\section{Nature of Writing}

According to Sokolik (in Nunan, 2003) states that writing the physical act of committing words or ideas to some medium, whether it is hieroglyphically inked onto parchment or an email message typed into a computer. On the contrary, writing is the psichological work of finding ideas, thinking about how to express them and organizing them into statements and paragraphs that will be clear to a reader. Brown (2007) views the result of thinking, drafting, and revising procedures that require specialized skills, skills that not every speaker develops naturally often includes written product. The result of the compositional character of writing has produced writing pedagogy that focuses students on how to generate ideas, how to organize them coherently, how to use discourse evaluaters and stylistic conventions to put them cohesively into a written text, how to revise text for clearer meaning, how to edit text for appropriate grammar, and how to produce a final product.

\section{The Process of Writing}

There are some activities in the process of writing skills. Brown (2007) explains that the process of writing refers to generating ideas, writing the first paragraph, peer-editing, and revising.

\section{a. Generating ideas}

First, we need to find ways to unlock the hidden ideas we have in our minds. In this unit, we have learned to use brainstorming, free writing, and looping. Try these techniques in any combination that works for us. Reading also helps to generate ideas. As we write, keep in mind the information. 


\section{b. Writing the first draft}

After exploring our ideas, put them into paragraph form, keeping in mind how showing and using facts and statistics makes writing powerful and convincing. Our task here is to discover how we can best express our ideas in the clearest manner possible so that our readers will receive the same message, with the impact, that we intended.

\section{c. Peer-editing}

What follows is an element of the writing process that is especially important: sharing what we have written with others, our readers, to see if we have been successful in conveying our intended meaning. This step can be a fascinating adventure. We step out of our own selves, to see what we have created through the eyes of others, to discover the impact of our words on the thoughts of our readers, so that we can then use the information to improve what we have written. We call this peer-editing. Peer-editing is a true sharing process. Not only do we get feedback from our classmates, but we also give feedback to them. It is a twoway street. We learn to be a better writer and a better reader. In the following exercise, we will work with several classmates, taking the roles of both reader and writer.

\section{d. Revising}

We have gotten feedback about our composition from several classmates. Now we can use what we learned about our writing to improve it, to make it clearer and more convincing. Writers call this step of the process revising. All good writers go through several steps of revision because they want to make their writing the best it can be. At this point, they reconsider what they have written, get feedback from others, and then make changes. Review our notes from our peer-editing session. Think about the comments made by our peer readers; in particular, comment they agreed on. If we agree with them, we can revise the piece. Remember, however, that we are the final judge as to what we want to include or eliminate in our writing.

\section{Types of Paragraphs}

According to Curriculum-Based competence/KTSP (Depdiknas, 2006), there are five skills in Junior High school for teaching writing, they are descriptive, procedure, recount, narrative and report texts, besides functional texts for some functional activities such as inviting people, requesting someone to do something, and getting the thing done. The descriptions of writing skill are taught in the Secondary School, as below: 


\section{Volume 5, Number 2, December 2019}

\section{a. Descriptive text}

It describes a particular person, place or thing. Its objective is to tell about the subject by describing its features without including personal opinions. A real description differs from an information report because it describes a specific subject rather than a general group.

It has two generic structures, they are identified phenomenon to be described, and describes parts; qualities, general attitude, and characteristics. Also, it consists of the language features, such as verb in the present tense, adjectives to describe the features of the subject and topic sentences to begin paragraphs and organize the various aspects of the description.

\section{b. Procedure text}

It is a piece of text that tells the reader or listener how to do something. Its objective is to provide instructions for making something, doing something or getting somewhere. It has generic structures; they are an introductory statement or title that gives the aim or goal of the procedure, followed by a list of materials that will be needed to complete the procedure. The final section is a sequence of steps, in the order, they need to be completed, to achieve this goal. It also has language features they are simple present tense, time words or numbers that show the order for carrying out the procedure, adverbs to describe how the action should be performed and precise terms and technical language.

\section{c. Recount text}

It is a piece of text that retells past events, usually in the order in which they occurred. It has three main sections, the first paragraph gives background information about who, what, where and when (orientation), followed by a series of paragraphs that retell the events in the order in which they happened. Some recounts have a concluding paragraph that may include a personal comment (not always necessary).

\section{d. Narrative text}

It is a text that tells a story and, in doing so, entertains the audience. The purpose of a narrative, other than providing entertainment, can make the audience think about an issue, teach them a lesson, or excite their emotions. It can be presented as written or spoken texts. It has language features, they are orientation, complication, the sequence of events, resolution, and coda. Also, it has language features: a noun that identifies the specific characters and places in the story, adjectives that provide accurate descriptions of the characters and settings, a verb that show the actions that occur in the story and time words that connect events, telling when they occurred. 


\section{e. Report text}

It is a piece of the text that presents information about a subject. Its objective is to classify and/or describe using facts about the subject's parts, behavior, and qualities. The subject is usually common rather than particular, for example, skin rather than an individual person's skin. It has generic structures, such as general classification and description. And also it has language features, they are technical language related to the subject, technical use of the timeless present tense, technical use of general nouns and linking verb to describe behavior or qualities.

\section{Writing Assessment}

Gronlund (2009) states that assessment is a process of getting useful information for evaluating the appropriateness of the objectives, the methods, and the materials of instructions.

Two important components in the assessment of writing are the nature of the task, or prompt, and the scoring criteria, or rubric (adapted from Cohen, 1994). Djiwandono (1997) states that writing prompt defines the task for the students writing an assessment. Two prompts include the question or statement students will address in their writing and the condition under which they will write. There are two kinds of writing prompts.1) single prompt, which offers the students to write based on the topic given. 2) Multiple prompts which offer the students to select the topic on which they prefer to write since the students have different topics.

\section{Pictures}

Picture as one of the media can be used as an instrument to stimulate students' learning (Finocchiaro, 1981) similarly, wright (1989) also mention that pictures can provide the students with that basic material for their composition and stimulate their idea.

Klasek (1990) states that still pictures or flat pictures include the entire range of two dimensional visual representations of people, places and things, which do not reproduce motion. Flat pictures include only non-projected, two dimensional, still pictures, usually drawn or printed on paper. The picture is a still medium which can suggest motion, emphasize key ideas and feeling, be studied by students individually, are easy in use, and could be discovered to picture several subject, concept, or instructional objective. And also they could be any color, size, representative or abstract. 


\section{a. Kinds of Pictures}

According to Andrew Wright (1989) mention types of pictures, such as: check chart, pictures of single objects, pictures of one person, pictures of famous people, pictures of several people, pictures of places, pictures from history, pictures with a lot of information, pictures of the news, pictures of fantasies, pictures of fantasies, pictures of maps and symbols, pairs of pictures, pictures and texts, sequences of pictures, related pictures, single stimulating pictures, ambiguous pictures, bizarre pictures, explanatory pictures, and student and teacher drawings. That can be used as media in teaching and learning process in the classroom and should consist of a file of pictures, which can be used to give interesting atmosphere, meaning practice in the sound structure, writing and tense of the foreign language.

\section{b. The Advantages of Using Pictures}

Pictures are familiar with visual aids, which have been used in ages by teachers in their teaching and learning activities. There are some advantages the teacher will take from using pictures. Several advantages are provided from their practice, availability, and effectiveness.

Dale (1996) cites that still, pictures have unique advantages of their own. They can take us closed to the very point of visual context with reality itself. They can also pack together or else manipulate actuality for teaching and learning purposes or replace the size of an object too small or too large to be visually comprehended in its actual dimensions. They allow us to travel to an unreachable place, to explore more, and to achieve a great many other learning.

\section{c. The Use of Pictures in Teaching Writing}

According to Wright (1983), teaching writing involves some activities: spelling, repetition, reproduction, manipulation, and composition. Pictures could be used as visual aids in the activities. Such as, in the first activity, it includes the students in going through a picture from magazine and students record all the objects or activities, which start with a specific letter or sound. The students may do in pairs or groups. The second activity is repetition. One example of repetition activity is that the teacher displays a number of questions and a number of answers in a jumbled sentence. The students write each question and correct answer. The third activity is a reproduction. Such as, the teacher keeps a list of flashcards of words.

\section{RESEARCH METHOD}

\section{Research Design}

This study uses a collaborative action research design. The researcher collaborated with an English teacher who observed and took notes during the implementation. Ary (2006) states 
that action research is used to interpret events and enable individuals or groups of people to formulate acceptable solutions to local problems.

The design of action research takes a cyclical process adapted from the model suggested by Kemmis and Mc. Taggart (1992). It has four main steps; planning, implementing the action, observing and reflecting. The cyclic process finishes whenever the problem has been solved.

\section{Setting and Subjects of the Research}

This research was conducted at the eighth graders. The number of population was 128 students divided into four classes, class VIII-A consisting of 32 students, class VIII-B consisting of 31 students, class VIII-C consisting of 33 students and class VIII-D consisting of 32 students.

\section{Research Procedure}

This study is classified as collaborative action research involving four stages: planning, implementing, observing, and analyzing and reflecting. The researcher did a preliminary research in order to get the real problems in the teaching of writing recount texts. See Figure 1 as follow.

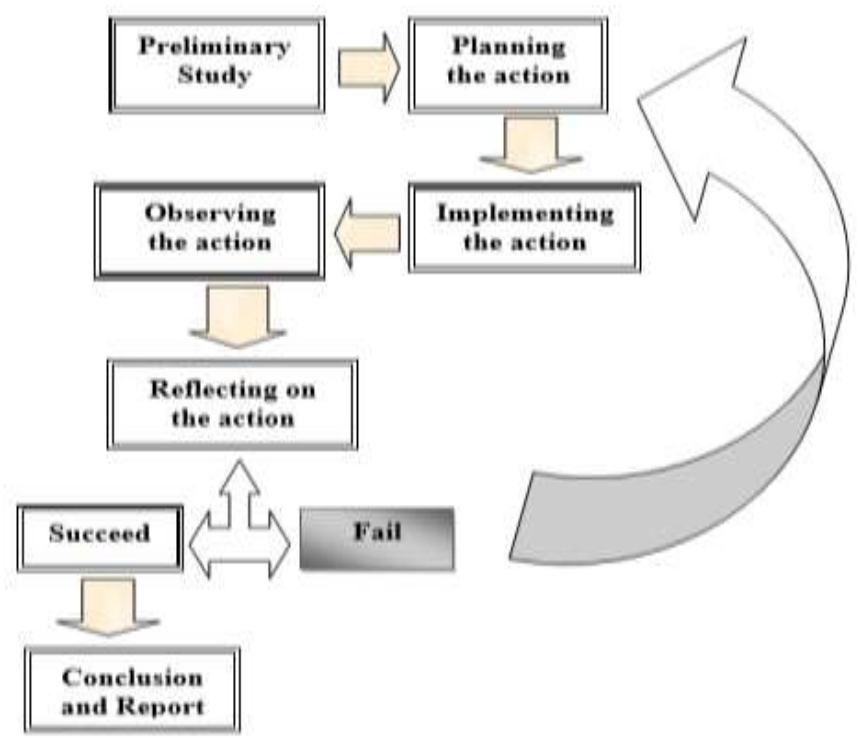

Figure 1 the Procedure of Classroom Action Research

(Adapted from Kemmis and Mc Taggart 1992)

\section{Data and Data Source}

In conducting this study, the researcher uses quantitative and qualitative data. Quantitative data are used to get the number of students who participate during the implementation of a writing process approach with the picture. Quantitative data are also 
taken from the result of questionnaires distributed to the students after the implementation of the writing process approach with the picture. Qualitative data are used to describe the students' interest in the writing process approach with the picture to improve their writing skill. Besides, qualitative data are taken from the observation, interview, and field notes. Qualitative data are in the form of description from the result of observation, interview, and field notes.

\section{The technique of Data Collection and Data Analysis}

There are four kinds of data collected that the researcher applies in this study. They are a questionnaire, observation sheets, interview, and field notes.

The use of questionnaire in this research study helps the researcher to gather clear and concisely structured feedback from the students about their attitude toward the approach implemented. The type of questions used in the questionnaire is multiple choice questions in which each item provides four different alternative options ( $a, b, c, d)$ to choose. There are five items on the questionnaire which may lead the researcher to come to a conclusion about the students' attitude. The result of the questionnaires is to reinforce the data on the students' active involvement gained from the observation sheets.

The observation sheets used in this research study are to gather data about the students' involvement in teaching learning activities. The technique of observation used is participant observation in which the researcher as a part of the action involved in doing observation and non-participant observation means that the observation is done by a collaborator who is sitting somewhere in the classroom, silent, but attentive to observe the students' involvement in the action. In this case, the observer fills in the observation checklist by putting a tick $(\sqrt{ })$ on one of the four indicators, one of the categories, and some columns available.

Then, the use of field notes is also very helpful for keeping a record of what happens, of why and where your ideas evolved and the research process itself. So, field notes refer to the written account of what the researcher hear, see, experience, and think in the course of collecting, evaluating, and reflecting on the data which might not be covered in the observation sheets, the students' self-assessment sheet, and the questionnaires. There are three points that are covered in field notes, they are: general point, good point, and point to improve.

\section{FINDINGS}

This section discusses the students' participation and students' writing achievement.

\section{a. The Students' Participation in the Teaching-Learning Process}


Most students completely kept their mind on the teacher's explanation. The students were always enthusiastic in asking and responding to the teacher's questions.

In the first meeting, 2 Students $(6 \%)$ were Superb Active (SA), 6 Students (20\%) were Very Active (VA), 9 Students (31\%) were Active Enough (AE), 6 Students (20\%) were Fairly Active (FA), and 6 Students $(20 \%)$ were Not Active (NA). Two students were absent in this meeting.

In the second meeting 4 Students (14\%) were Superb Active (SA), 5 Students (18\%) were Very Active (VA), 8 Students (29\%) were Active Enough (AE), 6 Students (20\%) were Fairly Active (FA), and 4 Students (14\%) were Not Active (NA). Four students were absent in this meeting.

In the third meeting, 7 Students $(23 \%)$ were Superb Active (SA), 7 Students $(23 \%)$ were Very Active (VA), 6 Students (20\%) were Active Enough (AE), 5 Students (16\%) were Fairly Active (FA), and 4 Students (13\%) were Not Active (NA). Two students were absent in this meeting.

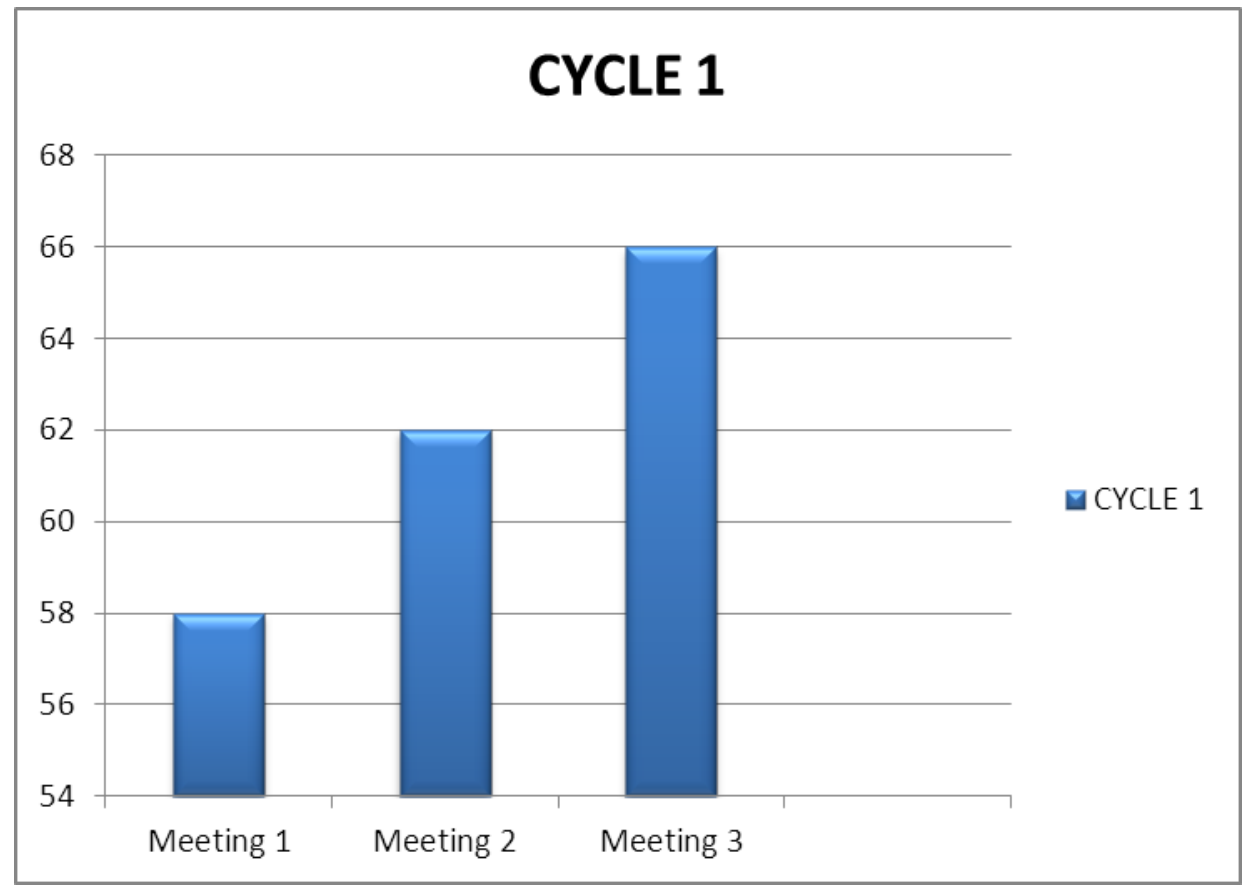

Figure 2 The Students' participation in the learning process for cycle one

It could be concluded that the students' participation in the learning process as carrying out the using pictures was good enough.

In the first meeting from the second cycle, 5 Students (16\%) were Superb Active (SA) as they met five of the indicators, 14 Students (46\%) were Very Active (VA), 4 Students (13\%) 
were Active Enough (AE), 3 Students (10\%) were Fairly Active (FA), and 4 Students (13\%) were Not Active (NA). One student was absent from this meeting.

In the second meeting of cycle two, 5 Students (16\%) were Superb Active (SA), 14 Students (46\%) were Very Active (VA), 4 Students (13\%) were Active Enough (AE), 3 Students $(10 \%)$ were Fairly Active (FA), and 4 Students (13\%) were Not Active (NA). All students were present at this meeting.

In the third meeting of cycle two, 7 Students (22\%) were Superb Active (SA), 12 Students (38\%) were Very Active (VA), 5 Students (16\%) were Active Enough (AE), 3 Students (9\%) were Fairly Active (FA), and 3 Students (9\%) were Not Active (NA). All students were present at this meeting.

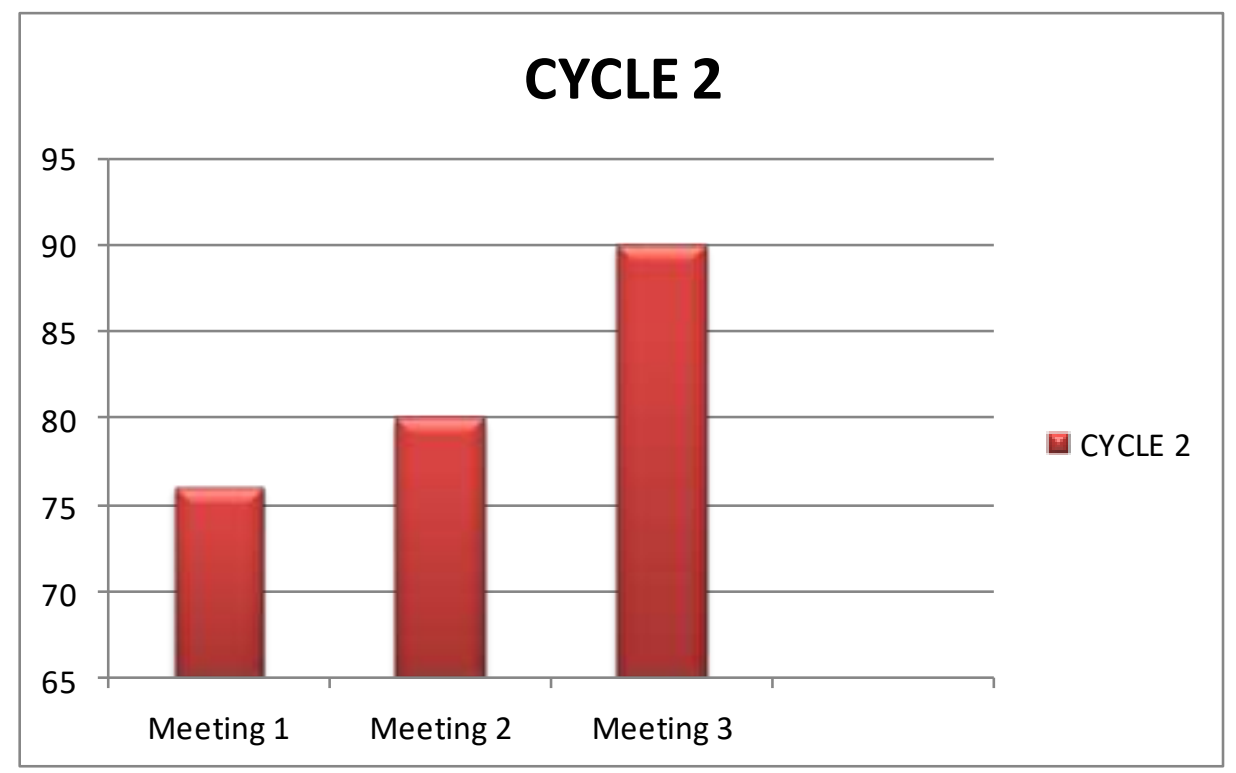

Figure 3 The Students' participation in the learning process for cycle two

From the data, it could be concluded that the students' participation in the learning process was very good.

\section{b. The Finding of Students' Writing Achievement}

The students did not have many problems to generate their ideas in the sentences because the pictures helped them recall their experiences in writing sentences. The pictures provided an easy way to write and lead them to arrange the chronological events. In the context of the organization, the students did not have any problem to write orientation, chronological events, and reorientation. The students had problems to write past tense in regular verb and irregular verb although they were trained to use a dictionary from the first meeting up to third meeting. They still had difficulties to write the story in English and their 
writing was influenced by Indonesian style. The students also had difficulties to write capital letters and articles. See figure 4. The example of students' writing in a group as below:

1. Please write a revised draft based on your friends' feedbacks

\section{MID-TEST}

Last year, I went to school. In the morning arrive at there. I came in class for did a test at 07.00 a.m. until 10.00 a.m.

Before that, I prepared touch. Then, my teacher gave a letter for all students. After that I read a test to answering the questions. I thought with carefull. Then I wrote answering a letter with carefull.

It was so difficult. I $\underline{\operatorname{sad}}$ when that come mid-test. but I very happy because I can meet with my friends

Figure 4 The example of students' writing in cycle 1

2. Please write your final draft

\section{MID-TEST}

Last year, I went to school. In the morning I arrived there. I came in class for doing a test at 07.00 a.m. until 10.00 a.m.

Before that, I prepared utensils. Then, my teacher gave a test for all students. After that I read a test to answer the questions. I thought with careful. Then I wrote answering a test with careful.

It was so difficult. I was sad when mid-test came. But I was very happy because I can answer the test.

See students' writing scores the figure 6 as below; 


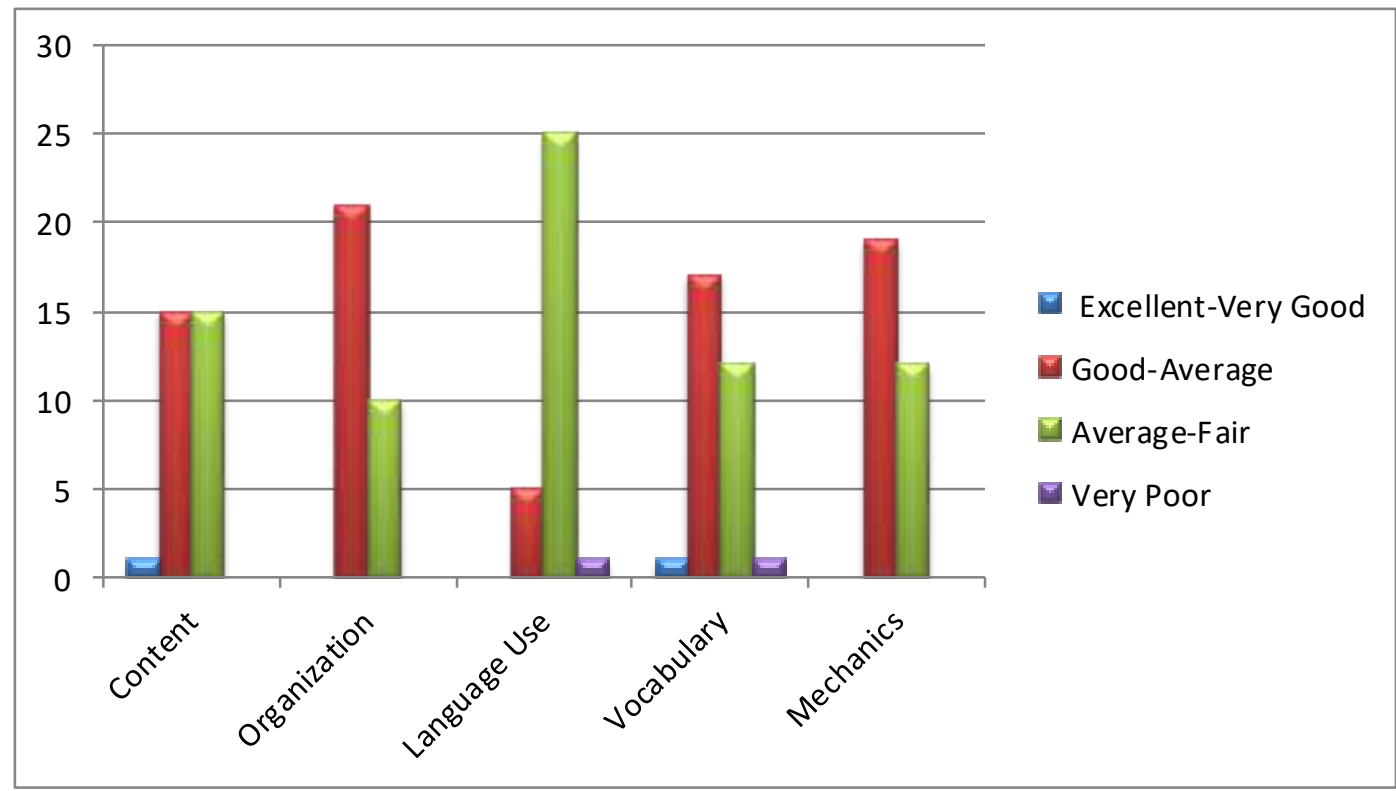

Figure 6 The Finding of Students' Writing Scores in Cycle One

From the students' average score, there was a student who got 86. It was the best score. In the other hand, the worst score was 45 . Overall, there were 16 students who got better than or equal to 70.00 and 15 Students who got less than 70.00. Hence based on the criteria of success that the students' writing scores got the scores better than or equal 70.00 , it could be concluded that the finding did not already meet the criteria of success because of only 16 of the students who got it.

In cycle two, it was known that the finding of students' writing scores has been improved. They were able to generate their ideas and upgraded the sentences into a paragraph. In the context of writing quality, several students performed their progress well. It could be seen from their progress how to write the sentences using grammar. During the peer-editing and revising steps, they performed their skill to edit the sentences and paragraph, and also to give feedbacks and revise the recount texts. The sample of students' writing in the group as follows:

1. Please write a revised draft based on your friends' feedbacks

\section{LEARNING IN THE SCHOOL}

I went to school at 05.45 a.m. with my friends by motorcycle.

In the school we followed ceremony. Then we stood in the yard.

After that we came to the class together and started lesson at 07.30 a.m.

untill 12.05 p.m. After that we went home

These activities added our knowledge and we felt happy although we were so tired. 
Figure 7 The example of students' writing in cycle 2

2. Please write your final draft

\section{LEARNING IN THE SCHOOL}

I went to school at 05.45 a.m. with my friends by motorcycle.

In the school we followed ceremony. Then we stood in the yard.

After that we came to the class together and started lesson at 07.30 a.m.

until 12.05 p.m. After that we went home

These activities added our knowledge and we felt happy although we were so tired.

Figure 8 The example of students' writing in cycle 2

See students' writing scores the figure 9 as below;

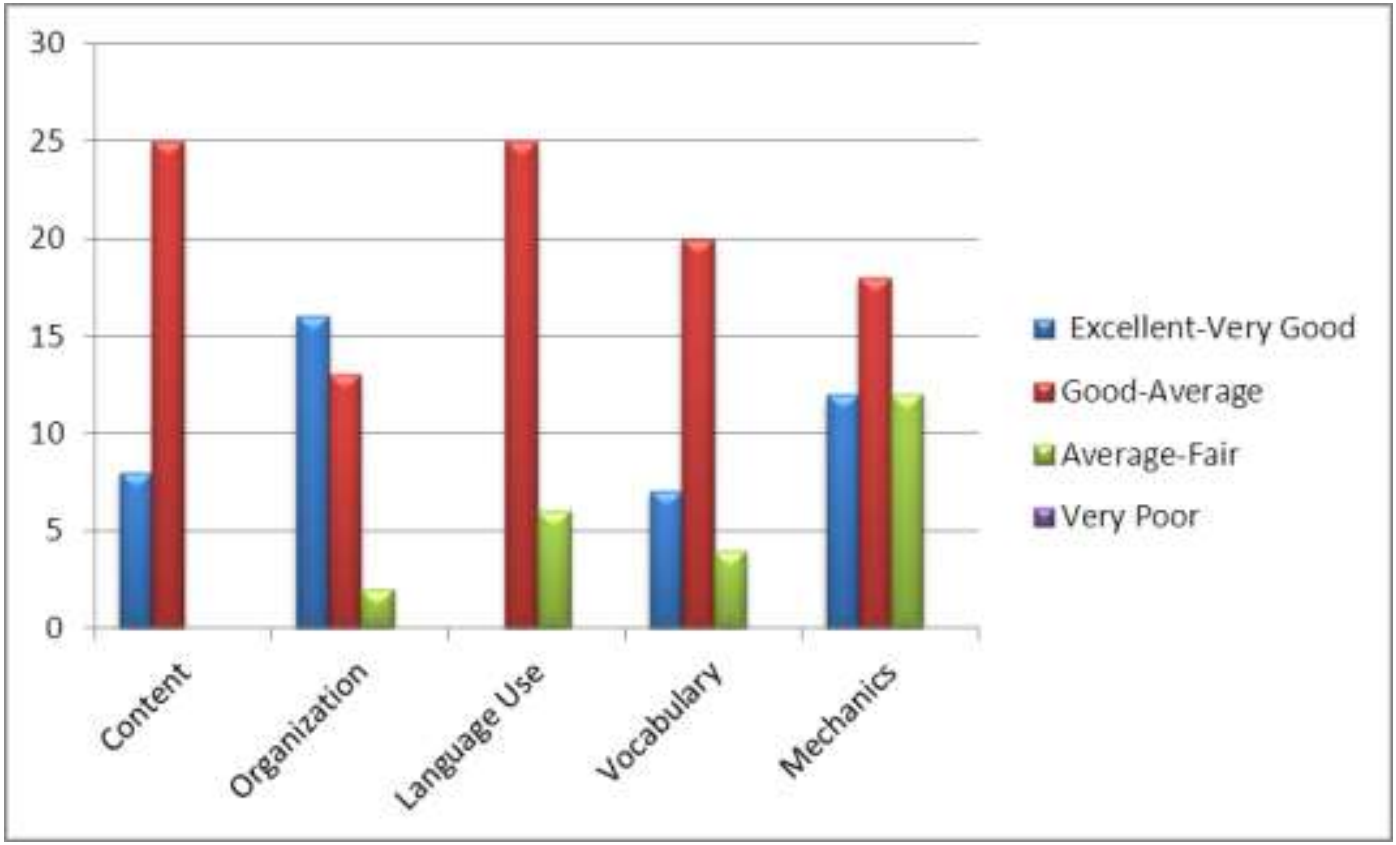

Figure 9 The Finding of Students' Writing Scores in Cycle Two

From the students' average score, there was a student who got 95. It was the best score. In the other hand, the worst score was 62 . Overall, there were 25 students who got better than or equal to 70.00 and 6 students who got less than 70.00 . Hence based on the 


\section{Volume 5, Number 2, December 2019}

criteria of success that the students' writing test got the scores better than or equal 70.00 , it could be concluded that the finding already achieved the criteria of success.

\section{Discussions}

This section covers the discussion of the results for instance: the activities in implementing the writing process approach with pictures and the achievement of the students' writing skill.

\section{a. Discussion on the Activities in Using Pictures}

Based on the finding of this study, it is evidence that the suitable strategy of teaching recount text by implementing a writing process approach with pictures needs the English teacher to conduct some procedures.

In the pre-activity step, first, the teacher explains the objectives of the teaching and learning activities. Second, the teacher starts the teaching and learning activities by asking their condition and feeling to make relax the good atmosphere between teacher and students in the classroom and asks them several questions in line with the topic to write. Third, the teacher makes some groups based on their relationship to share their knowledge with each other

In the whilst-activity, first, the English teacher displays the students some pictures of the topic they are going to write on the worksheets and on the whiteboard. Second, he distributes the worksheets with the pictures and the pictures must be color and big enough for all the students to look at. The teacher has to walk around where the students are sitting and ensure that the pictures are clear and could be seen clearly as suggested by Mandel, Adler et al. in Cottrell (1999). Third, he gives a model of how to generate their ideas by writing the keywords on the worksheets and enlightens the characteristics of recount texts, so the students do not compose other text-types. Fourth, he encourages the students' ideas to write on the rough draft and they may open the dictionary to find the difficult keywords and check verb 2 . Fifth, he assigns the students to write the first draft based on the generic structure of recounts. Sixth, he assigns them to discuss their first draft with their friends and teacher. In this part, the English teacher invites them to share and discuss their ideas they write. He always reminds them that irrelevant ideas have to be omitted; they can spoil the clarity of the meaning in the paragraphs. For that, the teacher always walks around to lead them and assigns them to read the pictures to find more ideas. Seventh, the English teacher asks them to exchange their draft to other groups, do peer-editing and check the content, organization, language use, vocabulary, and mechanics. In reality, the students only focus their correction on grammatical and mechanics aspects. This phenomenon is supported by Chenoweth in Cahyono (2001) that writers tend to correct only surface errors of grammar and punctuation or to change their 
choice of words. Eighth, the English teacher assigns asks the students to revise the draft. This opportunity is provided so that the students are able to review what they have written on the basis of the input or feedback from their friends as well as from the teacher and to correct the mistakes. Ninth, the English teacher asks them to publish and stick on the whiteboard.

In the post-activity, tenth, the English teacher assigns them to submit their final draft. Eleventh, the teacher asks the students what they have learned. Thirteenth, the teacher assigns the students to write recounts individually at home.

In the context of media, the pictures were used in inspiring and recalling the students' prior knowledge. In this research, the keywords were increased on the pictures which assisted the students to generate their ideas based on the pictures and keywords. While, they were admitted to using a dictionary to look for the meaning of vocabulary or find verb 2 , and discuss the materials using Indonesian and English which attended to assist the lower students and moderate achievers to take part actively in producing the sentences and chronological events.

During the teaching recount texts by implementing writing process approach with pictures, the English teacher is assigned to involve actively the students' interest in the writing process by relating the topic they will write with their prior knowledge, to make the clear instructions, and lead the students in the writing procedures. It is conducted especially when the students do not answer quickly at the beginning of teaching and learning activities. The teacher provides some questions in line with the topic. The teacher's instruction should be clear, and his voice should be louder for all the students to listen.

Although the instructional strategy has been done appropriately, it does not mean that automatically the students' skill progress. Their writing still has many mistakes in the area of content, organization, vocabulary, language use and mechanics. This problem appears because of the students' lack of experience in the writing process. To solve their vocabulary they may discuss, share with their friends and also open the dictionary. In the context of language use, the teacher should explain in details by practicing simple past tense with the focus of the sentence pattern of "Subject + Verb 2 + Object + Adverb". For the time being, when the students are assigned to combine from sentences to a form of paragraphs, they are asked to practice the use of conjunction such as and, also and however or the use of chronological order such as first, second, third, and so on. 


\section{b. The Achievement of the Students' Writing Skill}

The students' writing skill of recount text can be improved by implementing a writing process approach with pictures. The achievement can be measured from the findings of the students' writing based on the writing task provided in the classroom and from the findings of the writing test administered at the end of the cycles. Before this teaching strategy is conducted, the students faced some problems in English writing. Their writing consists of several mistakes in the area of content, organization, language use, vocabulary, and mechanics, therefore their writing is not understandable. In addition, the students were not able to distinguish the text types. Exercised with the teaching recount texts by using pictures, the students were able to produce the understandable recount text, as the area of the content and organization have been progressed meanwhile the number of mistakes has been decreased. The students had several improvements in writing recounts since the teacher always corrected and marked the mistakes in their writing. In addition, the students always shared suggestions and feedback from their friends during writing activities.

The proof that the students' writing skill had an achievement can also be measured from the percentage of the students who got the greater scores than or equal to 70.00 in the writing test administered at the end of the cycle one and cycle two.

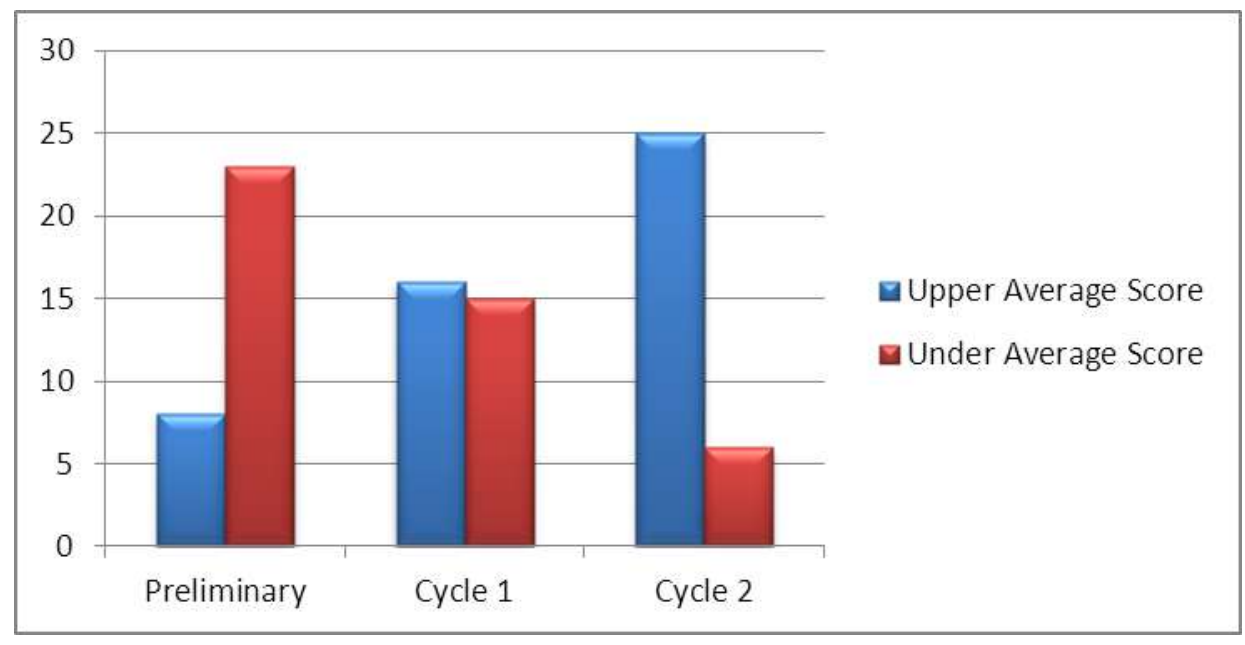

Note: Upper Average Score means equal to or greater than 70 Under Average Score means lower than 70

Figure 10 The Students' number who got equal to or more than 70

\section{E. CONCLUSIONS}


After the teaching recount text by implementing writing process approach with pictures is conducted and progressed through two cycles of this study, it is concluded that the suitable strategy of teaching recount texts by implementing writing process approach with pictures consists of six major steps and its procedure encompassed several essential activities. First, the English teacher displayed the students the pictures of a specific topic to be taught. The color pictures and worksheets are printed and distributed every group and attached on the whiteboard so that all the students can look at clearly. Second, the English teacher grouped the students into small groups and invited the students to find ideas based on the pictures. Several guiding questions are assigned to guide the students to generate their ideas of the pictures. The teacher guided the students to write their ideas and the keywords in the form of a list in the worksheets. Third, the English teacher asked the students to write sentences in line with the pictures based on the ideas they gathered. The English teacher asked several guiding questions to lead the students to write sentences orally. After correcting the students' oral sentences, the teacher asked in the form of worksheets. Fourth, the English teacher required the students to write recount texts based on the pictures they read. The students discussed with their friends to develop their draft into a short recount text. During this activity, they were assigned to read in details the pictures in the worksheets to avoid irrelevant writing ideas. Fifth, the teacher asked the students to exchange their draft and do peer-editing. The students were supposed to edit and write feedbacks from their friends and teacher based on the teacher's guidance. Sixth, the English teacher assigned the students to revise their draft based on their friends' feedbacks and write the final draft. After that, the students were asked to display their final draft before submitting to their teacher.

\section{REFERENCES}

Ary, D., Jacobs, L. C., Razavieh, A.\& Sorensen, C. (2006). Introduction to Research in Education Seventh Edition. Canada: Thompson Wadsworth.

Buehl, D. (2001). Classroom Strategies for Interactive Learning. Delaware: International Reading Association.

Brown, H. D. (2007). Teaching by Principles: An Interactive Oncoming to Language Pedagogy (second edition). New York: Addison Wesley Longman.

Cahyono, B. Y. (2001). Second Language Writing and Rhetoric. Malang: UM Press

Cahyono, B. Y. (2009). Teaching English with insights from linguistics. Malang: State University of Malang Press. 


\section{Volume 5, Number 2, December 2019}

Cohen, L., Manion. L, \& Morrison, K. (2004). A Guide to Teach Practice.London: Routledge Falmer.

Cottrell, S. (1999). The Study Skills Handbook. London: Macmillan Press.

Dale, E. (1969). Audio Visual Methods in Teaching. (3rd Edition). New York: Dryden Press.

Depdiknas. (2006). Peraturan Menteri Pendidikan Nasional Republik Indonesia: Permen nomor 22 Tabun 2006.

Djiwandono, M.S. (1999). Tes Bahasa dalam Pengajaran. Bandung: ITB Press.

Fachrurrazy. (2010). English Teaching as a Foreign Language for Teachers in Indonesia. Malang: State University of Malang.

Finocchiaro, M. and Bonomo, M. (1981). The Foreign Language Learner. New York: Rogents Publishing Company, Inc.

Gardner, P.S. (2005). New Directions: Reading, Writing, and Critically Thinking (2 ${ }^{\text {nd }}$ Edition). Cambridge: Cambridge University Press.

Harmer, J. (2007). The Practice of English Language Teaching. Edinburgh: Pearson Education Limited.

Kemmis, S. \& McTaggard, R. (1992). TheAction Research Planner. Third Edition. Victoria: Deakin University.

Klasek, C. K. (1990). Instructional Media in the Modern School. London: Macmillan Press.

Latief, A. (2010). Tanya Jawab Metode Penelitian Pembelajaran Bahasa. Malang: UM Press.

Nunan, D. (2003). Practical English Language Teaching First Edition. New York: The McGraw-Hill Companies.

Widiati, U. \& Cahyono, B. Y. (2006). The Teaching of EFL Writing in the Indonesian Context: The State of Art. Journal Ilmu Pendidikan, 13 (3): 139 - 150.

Wright, A. (1983). Vision Materials for the Language Teacher: Longman Handbooks for Language Teachers. Essex: Longman Group, Ltd.

Wright, A. (1989). Pictures for Language Learning. New York: Cambridge University Press. 